\title{
The Uses of Storytelling in Khaled Hosseini's The Kite Runner
}

\author{
Halit Hüseyni'nin Uçurtma Avcısı'nda Öykü Anlatımının Kullanımları
}

\author{
Karam NAYEBPOUR*
}

\begin{abstract}
In his The Kite Runner (2003), Khaled Hosseini uses storytelling for at least two purposes: to show how the firstperson narrator yearns to alleviate or at least control the profoundly destructive impact of a single past experience on his adult mind and to show how, through such a recollection and reconstruction process, the narrator feels satisfied with his atonement by the end of his narration. Storytelling helps Hosseini's narrator to reconfigure his unfavourable experiences, which act both as the central concern of the narrative plot and as a shared quality weaving the central characters together. Cognitive narratologists, such as Monika Fludernik and David Herman, consider representation of experience an important basic element of narrativity or the qualities that make a narrative accepted as narrative. By focusing on his personal and human-like experiences, the protagonist Amir's storytelling not only functions as a significant tool to alleviate his intense suffering, but also facilitates the readers' emotional engagement in Hosseini's storyworld.
\end{abstract}

Keywords: : storytelling, psychological Trauma, atonement, The Kite Runner, Khaled Hosseini.

$\ddot{\mathbf{O z}}$

Afgan asıllı Amerikalı yazar Halit Hüseyni (Khaled Hosseini) Uçurtma Avcısı (The Kite Runner) adlı romanında öykü anlatımını en az iki amaç için kullanmaktadır. Hüseyni’nin öyküsü bir yandan birinci şahıs anlatıcının geçmişteki bir deneyiminin yetişkin zihnindeki son derece yıkıcı etkisini hafifletmeyi veya en azından kontrol etmeyi, ne kadar istediğini gösterirken öte yandan bu tarz bir hatırlama ve yeniden yapılanma sürecinde anlatıcının, anlatım sonunda aldığı kefaretten ne kadar memnun olduğuna işaret eder. Öykü anlatımı, anlatıcının olumsuz deneyimlerini yeniden yapılandırmasına yardımcı olur. Hüseyni’nin öyküsündeki deneyim aktarımı hem öykü taslağının temel kaygısı hem de esas karakterleri biraraya getiren ortak bir özellik olarak yer alır. Monika Fludernik ve David Herman gibi bilişsel anlatıbilimciler, anlatımda tecrübeyi temsil etmeyi anlatısallığın veya öyküyü öykü yapan özelliklerin önemli unsurlarından biri olduğunu düşünmekteler. Kişisel ve insan benzeri deneyimlerine odaklanarak, kahramanı Amir'in öykü anlatımı, yoğun acılarını hafifletmek için önemli bir araç olarak işlev görmekle kalmaz, aynı zamanda okuyucuların Hüseyni’nin öykü dünyasına duygusal katılımını kolaylaştırmada büyük bir potansiyel oluşturur.

Anahtar sözcükler: öykü anlatma, psikolojik travma, telafi, The Kite Runner, Halit Hüseyni.

\section{Introduction}

Khaled Hosseini's The Kite Runner (2003) is a tragic account of the lifelong impact of a traumatic experience on the homodiegetic or first-person narrator's life and mentality. Hosseini's narrative shows how, through storytelling, the protagonist and narrator, Amir, struggles to come to terms with the double tragedy in his life. His narrative recounts the destruction of Amir's native land Afghanistan through two main wars in 1970s: the Russian Union occupation, and the Taliban insurgency. Additionally, it represents

\footnotetext{
* Dr. Öğr. Üyesi, Karadeniz Teknik Üniversitesi, İngiliz Dili ve Edebiyatı Bölümü
} 
the devastative impact of the socio-historical events on the lives of the central characters-Hassan and his wife are killed by the Taliban officers, Hassan's son Sohrab is sexually abused by another Taliban officer, and Amir's father and his closest friend Rahim Khan die from cancer abroad. Accordingly, Hosseini's narrative unfolds the destruction of one country and its inhabitants. As pointed out by David Jefferess, there have been "diverse approaches to interpreting the novel-as ethnography, coming-of-age narrative, and/or morality tale." Setting his study against this background, Jefferess argues that "the text's apparent humanizing function reflects current theories of a cosmopolitan ethics." In other words, he examines Amir's discourse "as an allegory of global ethics" (2009, p. 390). Although contextual interpretations of The Kite Runner reveal the richness of Hosseini's narrative, they mostly ignore its textual qualities. The main narrative concern in The Kite Runner, according to the restricted focus of my study, is to show how Amir uses storytelling as a multi-purpose tool in order to alleviate the psychological impact of a painful experience.

The Kite Runner is an exploration of the protagonist's struggles to find redemption or forgiveness for wrongdoing in his early adolescent life. As portrayed in his narrative, Amir aims to make up for his past maleficent behaviour toward his own half-brother. The desire for his narrative's progression is mainly triggered by the morality of possible redemption from a past cardinal sin, as well as by the need to seek forgiveness. Likewise, all other narrative events and situations revolve mostly around the consequences of a remarkable experience in the past. Accordingly, the enormous power of storytelling, as well as representation of the anthropomorphic, or lifelike, experiences in this narrative, allow the reader to form an emotional attachment to the inhabitants of Hosseini's fictional world. The act of writing helps Amir handle the evil side of his past life, which has intensely haunted him for three decades and reminded him what he could have done. His narrative of personal experience finally enables him to find atonement through rearrangement of past events. Amir endeavours to weaken the annoying presence of the past through his recollections, inner thoughts, writings, and finally an excursion to Kabul. Apart from his actions throughout the story, his writing also helps him reduce the dismantling impact of the past experience on his mind.

Hosseini's narrative, as Harold Bloom asserts, is a "grindingly sincere narrative in the shape of a memoir" (2009, p. 7). The centrality of a past experience in the narrative plot is implied from the story's opening, "I became what I am today at the age of twelve, on a frigid overcast day in the winter of 1975" (Hosseini, 2003, p. 1). The Pashtun narrator, according to Ronny Noor's review on The Kite Runner, "recounts the odyssey of his life" (2004, p. 147). He presents his life stories so naturally that their rich human-like aspects give the reader an illusion of experiencing actual historical events. The whole narrative is recounted in a retrospective mode. In the opening paragraph, the narrator informs us he received a call from his father's close friend, Rahim Khan, asking him to go back to Pakistan. Then, he recedes about twenty-five years into history and begins telling us his early adolescent life experiences. From here, his narration proceeds chronologically without any advanced use of narrative techniques, such as flashbacks or flash forwards. In the early 1970s, Kabul is peaceful and Amir, as an early adolescent, has a satisfactory life. In the subsequent years, the narrative recounts the falling process of the narrator's familial heaven.

As revealed through his narrative of confession, Amir lived a parallel life in America after his migration as his childhood memories in Kabul vex him consistently. He is repeatedly haunted by the memories related to Hazara Hassan, the son of Baba's servant, to whose sexual harassment he was once a silent witness. Hassan is a significant character both in the writer's representation, and in Amir's life and act of storytelling. According to Sarah O'Brien, Hosseini renders "Afghanistan's national trauma" through Hassan's character as he "frames Hassan's rape and its resultant trauma as an allegory for the turmoil engulfing Afghanistan following a coup in 1973 which toppled the monarchy and precipitated decades of political uncertainty, starting with a communist takeover and the invasion of Russian forces in 1979" (p. 4). Besides his contextual importance for the writer, Hassan is also a major character in the extradiegetic and diegetic levels or in the levels of narration and action at the same time. In Lee Erwin's words, Hassan "acts as a surrogate brother who is able to mediate between the narrator and his aloof father as well as ultimately, in the person of his own son, restoring wholeness to the narrator's marriage" (p. 327). The more Amir matures, the more he finds himself guilty of not taking any action to stop Assef from raping Hassan. Amir, however, uses storytelling as a healing tool, as well as atonement, for what he considers his 
sin. After his marriage and his father's death, he devotes himself to his writing career, and the narrative we read is that of his own life.

\section{Storytelling and Experience Representation}

Amir's storytelling, to quote Nünning and Sommer, acts "as an important means of characterization, and helps characters to overcome traumatic experiences" (2011, p. 220). Storytelling helps Amir, the author of his own narrative, decrease the psychological density of his traumatic past. Through reincarnating Hassan in his son, as well as putting his own life in danger to save him, Amir attempts to make amends for his earlier wrongdoings. Storytelling, additionally, helps him explore the impact of his own malignancy on the lives of the other(s). The outcome of such self-exploration is the development of awareness, which leads Amir to assuage his ever-suffering conscience. The narrativization of the past experiences, furthermore, allows him to reconfigure his subjectivity through merging the historical remains of the experiences with his present perceptions about them. The narrating Amir's subject, therefore, as Joao Biehl and Byron Good argue, "is at once a product and agent of history; the site of experience, memory, storytelling and aesthetic judgment; an agent of knowing as much as of action" (2007, p. 14). Amir's questing, and competing, subjects or selves not only intersect or draw on each other's experiences, memories, stories, and (re)judgments, but also enact what they discuss. The result of such enactment is the constructive (re)evaluation of the past deeds, which reveal some human-like aspects as well.

Storytelling in Amir's case is "more than a process of retrieving information from memory, selecting from it, and verbalizing it in serial, narrative form" (Norrick, 2007, p. 138). Rather, it helps the characters "create" and "recreate" their past in the light of their "present needs and concerns, instead of simply recapitulating stored experience" (Norrick, 2007, p. 139). Moreover, Amir's storytelling, to use David Herman's statement, "contributes primordially to the sense-making activities," which enable him and the other characters to "make sense of themselves, one another, and the world" (2009, p. 54). At the same time, Herman considers narrative a "mode of representation tailor-made for gauging the felt quality of lived experiences" (2009, p. 138). To explain his meaning, he borrows the term "qualia" or "what it's like for someone or something to have a particular experience" $(2009$, p. 144) from philosophy of mind. Amir's storytelling is his attempt to understand his own experience. He puts himself in a direct dialogue with the person he once hurt since, as Herman's explains, his "storytelling process entails a complex embedding or lamination of self- and other-positioning acts" (2009, p. 58). Moreover, although fictional characters are "ultimately semiotic constructs or creatures of the word," it is still, according to Uri Margolin's discussion, "the socially and culturally defined act of fictional storytelling that constitutes and defines them" (2007, p. 67). Accordingly, storytelling as a narrative element becomes a re-evaluation process for Amir.

Centrality of experience in Hosseini's narrative, furthermore, enriches the story's narrative quality. Representation of the impact of experience in narrative, according to the cognitive narratologists, can increase the narrativity level of a particular narrative, or "the set of properties charactering narrative and distinguishing it from nonnarrative" (Prince, 2003, p. 65). In other words, the more a narrative presents the effect of experience on the characters' thoughts and behaviour, the closer it is to the prototype narratives. Experience representation, according to Monika Fludernik, is the most distinguished property of any narrative's narrativity. Such representations include the potential to engage readers in fictional worlds through drawing on their real-life experiential frames. Calling this model "experientiality," or "the quasimimetic evocation of "real-life experience"' (2003, p. 9), Fludernik considers it the constituting element of narrative, which characterizes "the purpose and function of the storytelling as a process that captures the narrator's past experience, reproduces it in a vivid manner, and then evaluates and resolves it in terms of the protagonist's reactions and of the narrator's often explicit linking of the meaning of this experience with the current discourse context" (2003, p. 245). Likewise, representation of Amir's past experience reveals its impact on his current thoughts and discourse. Moreover, since the represented emotional experiences resemble real-life experiences, our emotional involvement in The Kite Runner grows considerably as we naturally tend to perceive the storyworld events and situations similar to Amir. The 
Kite Runner primarily represents a familiar frame - the envious feeling of early adolescence and its destructive consequences. This frame is universal in human society.

\section{Rhetoric of Storytelling in The Kite Runner}

In The Kite Runner, storytelling is the protagonist's intentional act of re-experiencing a past situation with an adult's perspective. The narrative begins from its end. Having received a call from his father's closest friend, Rahim Khan, Amir reveals to the reader that, "I knew it wasn't just Rahim Khan on the line. It was my past of unatoned sins" (2004, p. 1). Through his storytelling, Amir shares his own mental and physical struggles so that he might atone for his haunting action. Acting as an "evocation" (Fludernik, 1996, p. 9), Rahim Khan's words stir in his mind, "There is a way to be good again. [...] I thought about Hassan. Thought about Baba. Ali. Kabul. I thought of the life I had lived until the winter of 1975 came along and changed everything. And made me what I am today" (emphasis original, p. 2). Moreover, his storytelling is a re-evaluation of his own understanding of others', particularly Hassan's, actions. For example, when he remembers the first word he spoke was "Baba" and the first word Hassan spoke was "Amir," he re-evaluates Hassan's action, "Looking back on it now, I think the foundation for what happened in the winter of 1975 - and all that followed - was already laid in those first words" (2004, p. 11). His narrating I recounts the exasperating situations and events undertaken by his experiencing I in the past. Storytelling enables his awareness of the impact of his actions on others' lives, and this knowledge finally alleviates his pain.

Through his recounting, Amir discovers the main cause of his conflict with Hassan was his own obsessive adolescent jealousy of him. His narrating I's ironic perspective, however, reveals some deterministic sources of the problem as well. Admitting that "I never thought of Hassan and me as friends either," Amir points out some of the contextual reasons for that state, "Because history isn't easy to overcome. Neither is religion. In the end, I was a Pashtun and he was a Hazara, I was Sunni and he was Shi'a, and nothing was ever going to change that. Nothing" (2004, p. 25). Through his frank confession, however, Amir attempts to exorcise the uncomfortable feelings he once had about Hassan. His narrative reveals the conflict between his two adolescent inclinations. On the one hand, Amir realises he used to wonder about the illiterate Hassan's abilities. For example, he acknowledges, "Hassan was the perfect audience in many ways" (2004, p. 33), "He always knew when to say the right thing" (2004, p. 37), he was "incapable of lying" (2004, p. 44), "he was by far the greatest kite runner I'd ever seen" (2004, p. 52), "He was so goddamn pure, you always felt like a phony around him" (2004, p. 58), and "Hassan always understood about me [. . . ] he'd read me plenty" (2004, p. 60-61). On the other hand, he always found "something fascinating - albeit in a sick way-about teasing Hassan" (2004, p. 54). When Hassan questioned him, or indicated an independent thinking self, Amir felt "the insecure writer in me wasn't so sure he wanted to hear it. [. . .] A voice, cold and dark, suddenly whispered in my ear, What does he know, that illiterate Hazara? He'll never be anything but a cook. How dare he criticize you?" (emphasis original, p. 34). Such a state of in-betweenness is shown when Assef, condemning Amir, asks, "How can you call him your 'friend'? [. . .] If idiots like you and your father didn't take these people in, we'd be rid of them by now. They'd all just go rot in Hazarajat where they belong. You're a disgrace to Afghanistan" (2004, p. 41). Amir's inner perceptions reveal his dilemma at those moments,

But he's not my friend! I almost blurted. He's my servant! Had I really thought that? Of course I hadn't. I hadn't. I treated Hassan well, just like a friend, better even, more like a brother. But if so, then why, when Baba's friends came to visit with their kids, didn't I ever include Hassan in our games? Why did I play with Hassan only when no one else was around? (Emphasis original, p. 41)

Amir discovers that, unlike his age group who used to hate Hassan primarily for racial and religious reasons, he disliked him mainly because Hassan shared his father's attentions while Amir "Wished he'd let me be the favourite" (2004, p. 51). Moreover, Amir's storytelling shows how he tried to get rid of Hassan. The more he learned about Hassan's talents, the more he became aggressive toward him. For example, Hassan's ability to read his mind infuriated him, "How could I be such an open book to him when, half the time, I had no idea what was milling around in his head" (2004, p. 60-61). 
Amir's storytelling, furthermore, is a critical review of his own historical milieu. His personal adolescent perceptions are permeated with the contextual racial opinions about the Hazara from which his passivity toward Hassan's tragedy derives. For example, while he is looking for Hassan, an old merchant chides him for doing so, saying "What is a boy like you doing here at this time of the day looking for a Hazara?" (2004, p. 69). This statement is a sign of his society's biased perception of the Hazara and influences the adolescent Amir's world values on the verge of his entrance into the dominant discourse of racism. Therefore, Amir's storytelling changes into a process of real suffering. Recounting the deep rift between what he truly thought about Hassan and how he behaved toward him results in the narrating Amir's suffering.

Moreover, providing him with the retrospective account of his experiences, storytelling induces Amir to rebuild, or at least modify, his worldviews toward others. Through storytelling, he tries to rearrange such age-related and discourse-bounded perceptions. He also uses storytelling to shed light on his own long-lasting concerns about Hassan's perceptions of him at that time. As his narration reveals, the main reason behind the adolescents' vicious sexual assault on Hassan was the dominant social discourse about the Hazara. When Assef finds Wali and Kemal reluctant to comply with him in his assault, he tries to persuade them by saying, "It's just a Hazara" (2004, p. 75). This discourse, nevertheless, rekindles the protagonist Amir's evaluative comment on his own adolescent behaviour, "I had one last chance to make a decision. One final opportunity to decide who I was going to be. I could step into that alley, stand up for Hassan - the way he'd stood up for me all those times in the past - and accept whatever would happen to me. Or I could run" (2004, p. 77). His reflective narrative shows how his adolescent desire for selfproclamation, together with the social perspectives of the Hazara, assured he would "run away" at last leaving "the lamb" behind,

In the end, I ran.

I ran because I was a coward. I was afraid of Assef and what he would do to me. I was afraid of getting hurt. That's what I told myself as I turned my back to the alley, to Hassan. That's what I made myself believe. I actually aspired to cowardice, because the alternative, the real reason I was running, was that Assef was right: Nothing was free in this world. Maybe Hassan was the price I had to pay, the lamb I had to slay, to win Baba. Was it a fair price? The answer floated to my conscious mind before I could thwart it: He was just a Hazara, wasn't he? (2004, p. 77)

Amir, nevertheless, describes his experiencing self as being haunted with the above image not only during the succeeding weeks but also throughout the following years. Although, as he claims, that event made him "sick" (2004, p. 84), he finally could satisfy his protracted desire, "Baba and I were finally friends. [. . . ] I finally had what I'd wanted all those years. Except now that I had it, I felt as empty as this unkempt pool I was dangling my legs into" (2004, p. 85). Despite such a childish success, his narrative shows how the impact of his experience continues to cut into his consciousness afterward. As he recollects, “'I watched Hassan get raped,' I said to no one" (2004, p. 86). Even Hassan's presence makes him so uneasy he tries to get rid of him, "every time Hassan was around, I was getting a headache [. . .] when he was around, the oxygen seeped out of the room. [. . .] But even when he wasn't around, he was" (2004, p. 88-89). Such a sense of uneasiness provokes him to seek a way to get away from Hassan so that he might ease his self-condemning, torturing conscience. He even hits Hassan to make him angry so that he might hit him back, which would help Amir sleep peacefully at night,

"Hit me back!" I snapped. Hassan looked from the stain on his chest to me.

"Get up! Hit me!" I said. Hassan did get up, but he just stood there [. . .] I hit him with another pomegranate, in the shoulder this time. The juice splattered his face. "Hit me back!" I spat. "Hit me back, goddamn you!" I wished he would. I wished he'd give me the punishment I craved, so maybe I'd finally sleep at night. Maybe then things could return to how they used to be between us. But Hassan did nothing as I pelted him again and again. "You're a coward!" I said. "Nothing but a goddamn coward!"' (2004, p. 92) 
Hassan's patience both against Amir's aggressive behaviour toward him and about his rape equally annoyed Amir. As the adult Amir narrates, he and Hassan were mutually aware of their suffering. On his birthday, when Amir sees Hassan serving his own offenders, Wali and Assef, he murmurs to himself, "Maybe it would be for the best. Lessen his suffering. And mine too. Either way, this much had become clear: One of us had to go" (emphasis original, p. 102). Eventually, he succeeds in persuading his father to send Hassan and his father away and replace them. Amir hoped he could forget "the same image [that] kept flashing in [his] mind over and over" (2004, p. 102). When Hassan says "Yes" to Amir's request and willingly accepts that he stole his money, however, Amir is further demoralized,

This was Hassan's final sacrifice for me. [. . .] Hassan knew. He knew I'd seen everything in that alley, that I'd stood there and done nothing. He knew I had betrayed him and yet he was rescuing me once again, maybe for the last time. I loved him in that moment, loved him more than I'd ever loved anyone, and I wanted to tell them all that I was the snake in the grass, the monster in the lake. I wasn't worthy of this sacrifice; I was a liar, a cheat, and a thief. And I would have told, except that a part of me was glad. Glad that this would all be over with soon. Baba would dismiss them, there would be some pain, but life would move on. I wanted that, to move on, to forget, to start with a clean slate. I wanted to be able to breathe again. (2004, p. 105)

Amir, nevertheless, finds the same image haunting him after Hassan's physical absence as well, "My mind flashed to that winter day six years ago. Me, peering around the corner in the alley. Kamal and Wali holding Hassan down. Assef's buttock muscles clenching and unclenching, his hips thrusting back and forth" (2004, p. 116). Being haunted by Hassan and their mutual experiences continue throughout nearly twenty-five years of his subsequent life in America which, as he admits, "was a place to bury my memories" (2004, p. 129).

Amir's storytelling, accordingly, is an attempt to show how he was unable to forget the past and fulfil his desires after Hassan left. Thus, America acts as a symbolic place. He hoped his migration would help him to heal the pain in his soul,

America was different. America was a river, roaring along, unmindful of the past. I

could wade into this river, let my sins drown to the bottom, let the waters carry me someplace far. Someplace with no ghosts, no memories, and no sins.

If for nothing else, for that, I embraced America. (2004, p. 136)

The change in place, nevertheless, does not help Amir rid himself of his traumatic memory, which follows him everywhere. Once when they were talking about his would-be wife Soraya, the Afghanmigrant General Taheri's daughter, Amir's father implies the connection between Soraya's condition and her father's past. As the reader and the narrator are aware, he also refers to Amir's unchangeable condition as well, "It may be unfair, but what happens in a few days, sometimes even a single day, can change the course of a whole lifetime, Amir" (2004, p. 136). Even Soraya's entrance into his life does not help him forget Hassan as his mind repeatedly goes back to his past actions. When Soraya tells him how she helped their illiterate handmaid learn to read and write, Amir compares her story to his own treatment of Hassan, "I thought of how I had used my literacy to ridicule Hassan. How I had teased him about big words he didn't know" (2004, p. 151). His experience, however, enables him to accept Soraya. When she informs him about her past with an Afghan man, Amir, referring to his own experiences, tries to cope with the tense situation. His experience with Hassan helps him forgive Soraya for having a religiously, as well as culturally, unacceptable experience. As he shares with us through his story, on the one hand, he found Soraya's experience in conflict with his cultural codes, and on the other hand, he could not ignore his own past experiences, which were much worse than Soraya's one-month stay with a man when, as she admits to Amir, she was "rebellious" and "stupid" $(2004,164)$. His recollections, while speaking to Soraya, reveal the manner of his mental functioning at the time of narration. At the same time, they show his state after Hassan left their house in Kabul in 1976,

How could I, of all people, chastise someone for their past? [. . .] I envied her. Her secret was out. Spoken. Dealt with. I opened my mouth and almost told her how I'd betrayed Hassan, 
lied, driven him out, and destroyed a forty-year relationship between Baba and Ali. But I didn't. I suspected there were many ways in which Soraya Taheri was a better person than me. Courage was just one of them. (2004, p. 165)

Amir's unavoidable and incessant references to his past experience, therefore, motivate him to overcome his own now-unwanted cultural conventions, "I think a big part of the reason I didn't care about Soraya's past was that I had one of my own. I knew all about regret" (2004, p. 180). Nevertheless, although he knows his pain would decrease if he shared it with someone else, he cannot overcome the horror of his own actions and never dared divulge his secret. Accordingly, his storytelling functions as his only available immediate experience-sharing medium.

Hassan is the central concern of Amir's storytelling as he was the central part of his adolescent life experiences. His presence has filled Amir's life. When Amir looks at his wife's face for the first time under the veil, he sees it from Hassan's eyes, "I remember wondering if Hassan too had married. And so, whose face he had seen in the mirror under the veil? Whose henna-painted hands had he held?" (2004, p. 171). In this way, he lives a parallel life in his adulthood. He takes refuge in fiction as he decides to write down his experiences. Having published his first novel, he imagines Hassan's reaction to it, remembering his words, "And I thought of Hassan. Some day, Inshallah, you will be a great writer, he had said once, and people all over the world will read your stories. There was so much goodness in my life. So much happiness. I wondered whether I deserved any of it" (emphasis original, p. 183). His self-awareness of the impact of his own action and non-action on Hassan's life keeps those memories so fresh that he lives two lives simultaneously - one in his memories and the other in the present. He evaluates his actions based on his own behaviour toward Hassan. In other words, Hassan transforms into the touchstone of his life. Whenever he encounters a new situation, he evaluates it based on what he had done to Hassan. When he and Soraya learn they cannot have a child, Amir takes it as a retaliation for his deeds in the past, "perhaps something, someone, somewhere, had decided to deny me fatherhood for the things I had done. Maybe this was my punishment, and perhaps justly so. It wasn't meant to be, Khala Jamila had said. Or, maybe, it was meant not to be" (2004, p. 188).

\section{Rahim Khan's Call from the Past}

Rahim Khan's call from Pakistan changes Amir's life entirely. This call is the real moment of narrative commencement as well. It adds to Amir's yearning for atonement. Rahim Khan is the only living cord connecting Amir to his past, to his memories of their house in Kabul, and to Hassan and his fate after leaving their home. In addition, rather than alleviating his sense of guilt, Amir's revelation intensifies it because, for the first time, Amir learns his father, who he had always adored, once had sexual relations with Hassan's mother, and Hassan was, in fact, his unlawful half-brother. This knowledge, in addition to the news of Hassan's and his wife's murder by the Taliban, because they were Hazara, adds to Amir's sense of guilt about his past actions. Thus, he is motivated to travel to the war-stricken Afghanistan after some twenty-five years because saving Hassan's son, Sohrab, is the only way he can atone for his unbearable guilt. The need to relieve his guilt compels him to go to Kabul, where he encounters many other tragic events and relentlessly pursues an act of retaliation. After taking Sohrab to America to save him from the assaulting world of Afghanistan, Amir aspires to alleviate his own sense of guilt.

Rahim Khan's call can be read as a symbolic summons from the past from which Amir had always been consciously running. Since he interprets the call as "my past of unatoned sins" (2004, p. 1), he complies with Rahim Khan's request mainly because of his own inner inclination, kept mostly in his subconscious, to atone for those sins. Moreover, Rahim Khan's last words encourage him to take action to emancipate himself from the enslaving impact of his past experience,

Come. There is a way to be good again, Rahim Khan had said on the phone just

before hanging up. Said it in passing, almost as an afterthought.

A way to be good again. (2004, p. 192)

The closer he geographically comes to his past, the more he is haunted with the grotesque nature of his past actions there. When in Peshawar, Pakistan, Rahim Khan tells him that after they left he lived in their house with Hassan for some years. Amir is reminded of his past life, "When was the last time I had 
spoken his name? Those thorny old barbs of guilt bore into me once more, as if speaking his name had broken a spell, set them free to torment me anew. Suddenly the air in Rahim Khan's little flat was too thick, too hot, too rich with the smell of the street" $(2004$, p. 202). Accordingly, Amir again suffers a great mental torment. This state, nevertheless, adds to his yearning and desire to continue his quest into the past so that he might be able to soothe his pain.

Rahim Khan's story helps Amir understand more about both his past life and the people around him at that time. His embarrassing revelation to him about Hassan's real father pushes Amir toward "an unbearable emptiness" (2004, p. 204) when, with a shout of pain, he cries, "Why? What can you possibly say to me? I'm thirty-eight years old and I've just found out my whole life is one big fucking lie! What can you possibly say to make things better? Nothing. Not a goddamn thing!" (2004, p. 223). This, however, emboldens him to turn back to his past life in Kabul so that he might atone not only for his own cardinal sin but also for the mysterious sin of his father as well. The moment he learns that he and his father equally deteriorated Hassan's and his father Ali's lives, he becomes determined to go to Kabul to help Hassan's son Sohrab, "Baba and I were more alike than I'd ever known. We had both betrayed the people who would have given their lives for us. And with that came this realization: that Rahim Khan had summoned me here to atone not just for my sins but for Baba's too" (2004, p. 226). Moreover, as Rahim Khan reveals to him in a letter, "Your father, like you, was a tortured soul" (2004, p. 301), Amir feels an inner compulsion to go back to their house in Kabul to help Hassan's son so that he might soothe his "tortured soul" through "creat[ing] good out of his remorse" (2004, p. 303).

Rahim Khan acts as a link between Amir's present and past lives. He encourages him to reexperience his own past. In Taliban's Kabul, Amir revisits his own childhood through Assef and his friends. He learns that the same people who raped Sohrab's father nearly twenty-five years ago are now raping his son. The only difference is that Amir intentionally takes action this time to rescue Sohrab from their hands. He even blinds Assef. When, ashamed of his own situation, Sohrab says to Amir, "I'm so dirty and full of sin," Amir replies, "You're not dirty at all" (2004, p. 319). This moment is the final scene of Amir's journey into the past. He takes Sohrab to a hospital in Peshawar, Pakistan, and applies for his visa for the USA. This also encourages him to reveal his story, related to Sohrab, his father and grandfather, to his wife Soraya,

Then I did what I hadn't done in fifteen years of marriage: I told my wife everything. Everything. I had pictured this moment so many times, dreaded it, but, as I spoke, I felt something lifting off my chest. I imagined Soraya had experienced something very similar the night of our khastegari, when she'd told me about her past. (2004, p. 325)

His own experiences in Kabul enlarge Amir's theory of mind. Under their influence, he readily sympathised with Soraya when she disclosed her background to him on their proposal night. Likewise, his experience and its representation in his narrative encourage him to acknowledge his own previous mistakes, "I have betrayed, lied, and sinned" (2004, p. 346). In Sohrab's life, Amir finds his own old life mirrored, "I didn't know what to say, where to look, so I gazed down at my hands. Your old life, I thought. My old life too" (emphasis original, p. 354). The more he remembers his old life with Sohrab's father, Hassan, the more he feels compelled to help Sohrab,

As I waited for his reply, my mind flashed back to a winter day from long ago, Hassan and

I sitting on the snow beneath a leafless sour cherry tree. I had played a cruel game with Hassan that day, toyed with him, asked him if he would chew dirt to prove his loyalty to me. Now I was the one under the microscope, the one who had to prove my worthiness. I deserved this. (2004, p. 355)

In this way, Hassan's son Sohrab acts as a gold cord connecting Amir to his past life. He enables him to expiate his sins. After a long period of inner conflict, he finally finds a catharsis through his retrospective combination of fear, about what he did to Hassan, and pity, particularly with Hassan's son and Soraya. He shares the joys of kite flying with Sohrab as he did in his early adolescent life with Hassan, "I ran with the wind blowing in my face, and a smile as wide as the Valley of Panjsher on my lips" (2004, p. 371). The final sentence of the narrative, "I ran," carries two implications. It refers to Amir's present rejoicing experience with Hassan's son Sohrab, and it reveals Amir's repressed desire to 
move farther away from his adolescent experiences with Hassan. In both cases, however, his life is embedded in Hassan's life.

\section{Conclusion}

Storytelling in The Kite Runner functions as a catalyst for the recovering process of the narrator from a psychological trauma. Hosseini's narrative is about the big impact of protracted conflicts on the narrator's life. By writing down his traumatic memories, Amir tries to understand his own past life. His storytelling is his natural ability, which enables him to reconcile himself to his unforgettable past. Under the effect of recounting, he criticizes his previous or younger self for what he did to his own half-brother. Furthermore, he regains his lost integrity by saving his nephew's life towards the end of narrative. Accordingly, storytelling in The Kite Runner acts as a narrative tool, which serves at least two purposes. First, by recreating the narrator's painful experience, storytelling enables him to find a way to atone for what he considers his past guilt. Amir's creative imagination provides him with a chance to compensate for his past evil deeds. For example, he fulfils his desire to save Hassan and sympathise with Soraya. Second, storytelling reveals the dramatic impact of Amir's unfavourable experience on his adult life and mentality. In other words, it enables him to encounter with the origin of his mental suffering. Storytelling qualifies Amir to release himself from the chains of the past as it encourages him to face with the evil nature of his previous thoughts and actions. Therefore, storytelling facilitates Amir's mental healing through reordering his past experiences. By reviving his early adolescent aggressive behaviour, storytelling attenuates the destructive impact of his traumatic experience. By the end of his story, Amir satisfies his psychological cravings to find his own atonement and forgiveness. Similarly, his confessional discourse and human-like experiences engage us emotionally with his narrative and arouse our sympathy toward his situation.

\section{References}

Biehl, J., Good, B., Kleinman, A. (2007). Subjectivity: Ethnographic Investigations Introduction: Rethinking Subjectivity. In J. Biehl, B. Good, and A. Kleinman (Eds.), (pp. 1-23). Berkeley: University of California Press.

Bloom, H. (2009). Bloom's guides: Khaled Hosseini's the kite runner (pp. 7-8). New York: Bloom's Literary Criticism.

Lee, E. (2012). Domesticating the subaltern in the global novel in English. The Journal of Commonwealth Literature, 47(3), 325339.

Fludernik, M. (1996). Towards a 'natural' narratology. London: Routledge.

Fludernik, M. (2003). Natural Narratology and Cognitive Parameters. In D. Herman (Ed.), Narrative Theory and the Cognitive Sciences (pp. 243-267). Stanford, CA: Centre for the Study of Language and Information.

Herman, David. (2009). Basic elements of narrative. Oxford: Willey-Blackwell.

Hosseini, Khaled. (2003). The Kite Runner. New York: Riverhead Books.

Jefferess, David. (2009). To be good (again): The Kite Runner as allegory of global ethics. Journal of Postcolonial Writing, 45(4), 389-400.

Margolin, Uri. (2007). Character. In D. Herman (Ed.), The Cambridge Companion to narrative, David Herman (pp. 67-79). New York: Cambridge University Press.

Norrick, Neal R. (2007). Conversational storytelling. In D. Herman (Ed.), The Cambridge Companion to narrative (pp. 127-142). New York: Cambridge University Press.

Nünning, Ansgar and Roy Sommer. (2011). The performative power of narrative in drama: On the forms and functions of dramatic storytelling in Shakespeare's plays. In G. Olson (Ed.), Current Trends in Narratology (pp. 200-231). Berlin: Walter de Gruyter.

O’Brien, Sarah. (2018). Translating trauma in Khaled Hosseini's The Kite Runner. Transnational Literature, 10(2) 1-12.

Prince, Gerald. (2003). A Dictionary of Narratology. Lincoln: University of Nebraska Press.

Ronny, Noor. (2004). The Kite Runner by Khaled Hosseini. World Literature Today, 78(3/4) 148. 